\title{
MODAL SOSIAL DALAM IMPLEMENTASI PROGRAM PENGUATAN -LEMBAGA DISTRIBUSI PANGAN MASYARAKAT (LDPM) DI KABUPATEN TANJUNG JABUNG BARAT
}

\author{
Rendra \\ Dosen Jurusan / Program Studi Agribisnis Faperta Unja \\ Email :yudra09@gmail.com
}

\begin{abstract}
ABSTRAK
Penelitian ini bertujuan untuk mengetahui modal sosial implementor dan kelompok sasaran dalam implementasi Program Penguatan-Lembaga Distribusi Pangan Masyarakat (LDPM) di Kabupaten Tanjung Jabung Barat baik dalam aspek Tim Teknis Kabupaten, Pendamping (PPL) maupun aspek Kelompok Sasaran (Pengurus dan Anggota Gapoktan). Penelitian ini dilakukan pada Gapoktan Sumber Rezeki di Desa Teluk Ketapang Kabupaten Tanjung Jabung Barat selama dua bulan. Penelitian ini dilakukan dengan menggunakan pendekatan kualitatif, sementara metode yang dipakai di dalam penelitian ini adalah metode wawancara mendalam dengan informan dari berbagai sumber, melakukan pengamatan lapangan untuk mengamati interaksi sosial dan komunikasi yang terjadi di dalam kelompok sasaran dan melakukan studi kepustakaan dengan mendapatkan referensi dan dokumentasi yang relevan. Hasil Penelitian menunjukkan bahwa Pemanfaatan modal sosial yang digunakan oleh implementor dalam implementasi program P-LDPM tersebut sangat membantu di dalam kelancaran pelaksanaan kegiatan di dalam program tersebut terutama di dalam memanfaatkan semangat kerjasama dan gotong royong serta solidaritas yang tinggi dalam saling tolong menolong dan merasa senasib sepenanggungan di kalangan petani anggota Gapoktan Sumber Rezeki di desa Teluk Ketapang dalam aspek Tim Teknis Kabupaten, Pendamping (PPL) dan Kelompok Sasaran (Pengurus dan Anggota Gapoktan). Di samping itu, terdapat peran tokoh masyarakat yang dominan dan adanya peran Ketua Gapoktan yang sangat sentral di dalam menjalankan kegiatan di dalam implementasi program. Dengan kata lain, modal sosial trust lebih banyak digunakan dibandingkan modal sosial lainnya.
\end{abstract}

Kata Kunci : Modal Sosial, Implementor dan Kelompok Sasaran, dan Implementasi Program Penguatan - Lembaga Distribusi Pangan Masyarakat (LDPM).

\begin{abstract}
The objectives of this research are to know the social capital of the implementor and the target group in the implementation of the Strengthening Program of Community Food Distribution Institution (LDPM) in West Tanjung Jabung Regency both in the aspect of the District Technical Team, the Assistant (PPL) and the aspect of the Target Group (Gapoktan Board and Members). This research was conducted at Gapoktan Sumber Rezeki in Teluk Ketapang Village, Tanjung Jabung Barat Regency for two months. This research is conducted by using qualitative approach, while the method used in this research is the method of in-depth interviews with informants from various sources, conducting field observations to observe social interaction and communication that occur within the target group and conduct literature study by getting references and documentation which is relevant. The results of the research show that the utilization of social capital used by the implementors in the implementation of P-LDPM program is very helpful in the smooth implementation of activities within the program, especially in utilizing the spirit of cooperation and mutual cooperation and solidarity in the mutual help and feel the same fate among farmers members of Gapoktan Sumber Rezeki in Teluk Ketapang village in the aspect of District Technical Team, Assistant (PPL) and Target Group (Gapoktan Board and Members). In addition, there is a dominant role of community leaders and the role of Chairman of Gapoktan which is very central in carrying out
\end{abstract}


activities in the implementation of the program. In other words, social trust capital is used more than any other social capital.

Keywords: Social Capital, The Implementor and The Target Group, and Implementation of Strengthening Program - Community Food Distribution Institution (LDPM).

\section{PENDAHULUAN}

Pelaksanaan program Penguatan - LDPM merupakan kegiatan bersama antara Pemerintah Pusat, Pemerintah Daerah dan Masyarakat dengan semangat utuk memperkuat kemampuan Gapoktan dalam membantu petani anggotanya khususnya dalam menjaga stabilitas harga gabah/beras dan memperkuat aset untuk penyimpanan dan cadangan pangan yang dimiliki Gapoktan maka dengan peran dan partisipasi dari pengurus dan anggota Gapoktan menjadi prioritas utama sebagai pelaku untuk mencapai keberhasilan dari kegiatan ini.

Gambar. 1. Diagram Organisasi Pelaksanaan Penguatan - LDPM

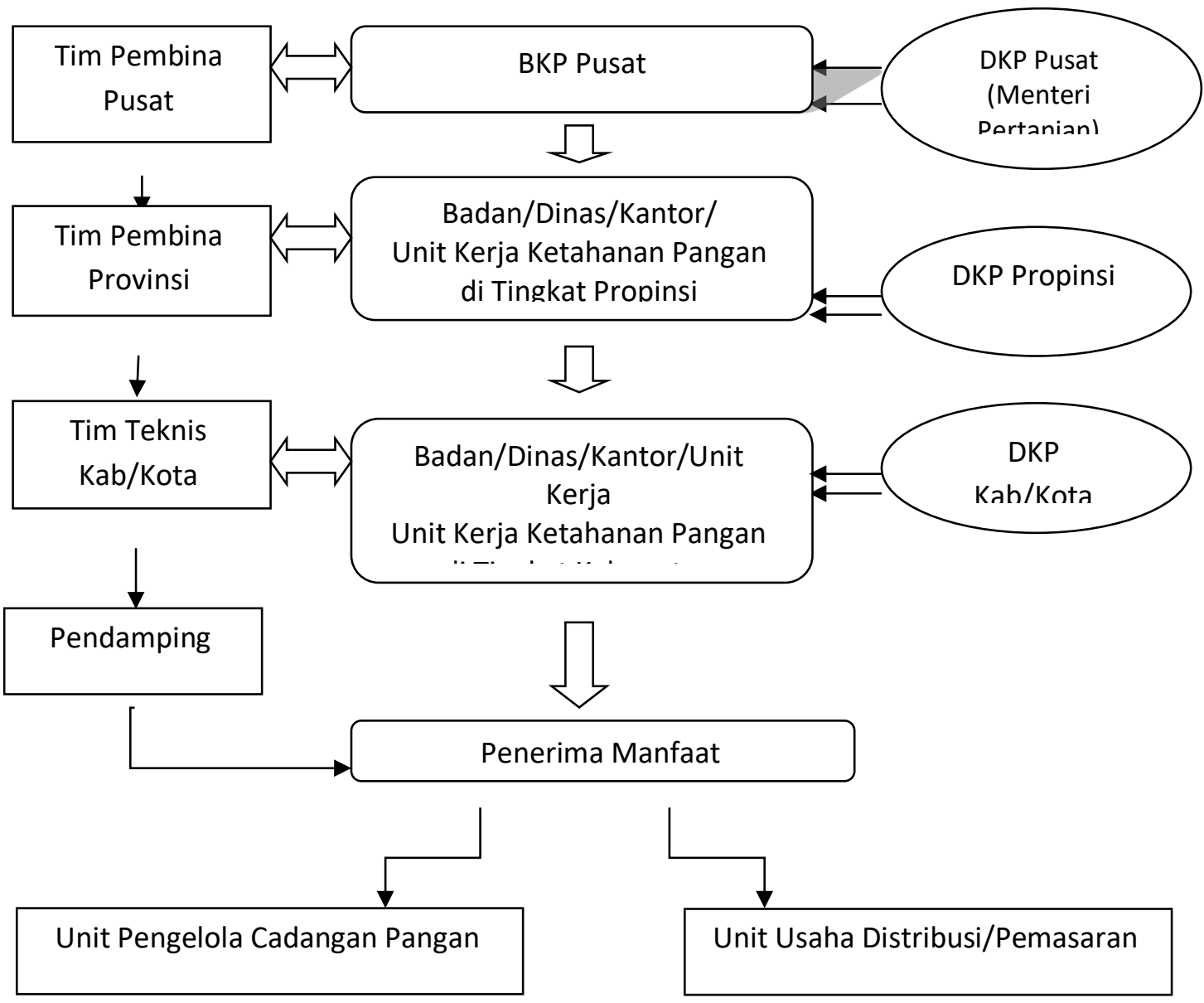

Keterangan :

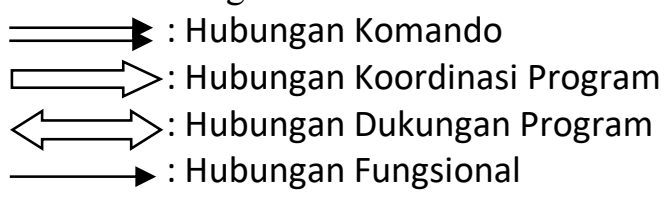

Sumber : BKP Propinsi Jambi (JUKLAK P-LDPM) 2014. 
Di Kabupaten Tanjung Jabung Barat terdapat 6 (enam) Gapoktan yang sudah melakukan program ini dari tahun 2009 sampai 2012, diantaranya : Gapoktan Agro Tani Sejahtera dan Sumber Rezeki pada tahun 2009 dimana gapoktan ini sudah memasuki tahap pasca kemandirian, Gapoktan Usaha Makmur dan Senyerang Jaya pada tahun 2010 dimana gapoktan ini sudah memasuki tahap kemandirian, dan Gapoktan Sungai Rambai pada tahun 2011 dimana sudah memasuki tahap pengembangan dan Gapoktan Lumahan Makmur tahun 2012 dimana baru memasuki tahap penumbuhan.

Berdasarkan data laporan perkembangan pelaksanaan kegiatan P-LDPM seluruh gapoktan yang ada di Kabupaten Tanjung Jabung Barat Tahun 2012, diketahui gapoktan Sumber Rezeki dan gapoktan Agro Tani Sejahtera mengalami perkembangan yang sangat signifikan yaitu dalam pelaksanaan kegiatan unit distribusi dan pemasaran gapoktan Sumber Rezeki dari bulan Januari s/d Oktober 2012 dimana pembelian beras pada bulan Januari s/d Oktober 2012 mencapai $220.250 \mathrm{Kg}$ dengan nilai sebesar Rp. 1.448.180.000,-. Sedangkan penjualan beras periode Januari s/d Oktober 2012 mencapai $224.660 \mathrm{Kg}$ dengan nilai sebesar Rp. 1.583.930.000,-. Sementara pelaksanaan kegiatan unit distribusi dan pemasaran gapoktan Agro Tani Sejahtera dari bulan Januari s/d Oktober 2012 dimana pembelian beras pada bulan Januari s/d Oktober 2012 mencapai $204.580 \mathrm{Kg}$ dengan nilai sebesar Rp. 1.392.063.000,-. Sedangkan penjualan beras periode Januari s/d Oktober 2012 mencapai $276.300 \mathrm{Kg}$ dengan nilai sebesar $\mathrm{Rp}$. 1.951.820.000,-. Pada pengelolaan unit pengolahan/penggilingan pada gapoktan Sumber Rezeki dan Agro Tani Sejahtera kedua-duanya nihil. Sedangkan pada pengelolaan unit cadangan pangan gapoktan Sumber Rezeki juga nihil dan gapoktan Agro Tani Sejahtera terdapat pembelian gabah periode bulan Januri s/d Oktober 2012 sebanyak 5.000 Kg dengan nilai Rp. 36.000.000,-.

Menurut Juklak pelaksanaan program Penguatan-LDPM tahun 2014, salah satu indikator keberhasilan dari tahap pasca kemadirian dalam pelaksanaan kegiatan Penguatan-LDPM adalah meningkatnya volume pembelian-penjualan gabah/beras di gapoktan pada unit usaha distribusi/pemasaran/pengolahan lebih dari dua kali putaran.

Implementor di dalam program Penguatan-Lembaga Distribusi Pangan Masyarakat ini adalah pihak Pemerintah sebagai tim teknis, mulai dari pemerintah pusat, pemerintah daerah propinsi sampai pada pemerintah daerah kabupaten. Guna mengimplementasikan program tersebut, Pemerintah Kabupaten Tanjung Jabung Barat telah membentuk Tim Teknis.

Program Penguatan - Lembaga Distribusi Pangan Masyarakat merupakan kegiatan dalam rangka meningkatkan kemampuan Gapoktan di wilayah sentra produksi padi agar mampu membantu anggotanya dalam mendistribusikan/memasarkan/mengolah hasil produksi pangannya disaat menghadapi panen raya dan mampu menyediakan pangan bagi kebutuhan anggotanya disaat menghadapi paceklik. Pada umumnya disaat panen raya bersamaan dengan datangnya musim hujan, dimana petani mengalami kesulitan untuk mengeringkan gabah sehingga mereka menjual kepada pelepas uang dengan harga yang sangat murah. Dampaknya harga gabah/beras di tingkat petani jatuh sehingga petani sebagai produsen pangan selalu berada pada posisi yang kurang menguntungkan.. sedangkan di sisi lain petani disaat mereka tidak mempunyai panen (saat paceklik), maka petani akan menjadi konsumen, sehingga mereka membutuhkan akses terhadap pangan untuk kebutuhan anggota keluarganya.

Mengingat petani selalu berada pada posisi yang kurang menguntungkan disaat menghadapi panen maupun menghadapi paceklik, Pemerintah memfasilitasi dan mendorong petani untuk tidak berjalan sendiri-sendiri tetapi dapat membangun kebersamaan dalam bentuk kumpulan petani dalam satu kelompok tani (Poktan) ataupun bergabung dalam bentuk gabungan kelompok tani (Gapoktan). Dengan adanya kesamaan kepentingan dan kesamaan masalah yang dihadapi, sehingga mereka mempunyai kekuatan yang sama untuk meningkatkan posisi tawar khususnya dalam mendistribusikan hasil panennya pada saat panen raya maupun mengembangkan jejaring pemasaran dengan mitra usahanya sehingga dapat memberikan keuntungan bagi Gapoktan dan anggotanya.

Program Penguatan-LDPM, dilaksanakan sejak Tahun 2009 yang bersumber dari dana dekonsentrasi APBN dari Badan Ketahanan Pangan Kementerian Pertanian. Melalui kegiatan Penguatan-LDPM disalurkan dana bantuan sosial (Bansos) langsung ke Gapoktan kegiatan pembelian dan penjualan gabah/beras serta membangun gudang sebagai sarana penyimpanan beras/gabah. Melalui kegiatan tersebut, pemerintah mendorong Gapoktan agar mampu memberdayakan seluruh 
sumberdaya yang dimiliki dalam upaya meningkatkan daya saing dan pendapatan serta kesejahteraan anggota.

Bagi petani-petani yang berada dalam wadah Gapoktan, dapat terpenuhi kebutuhan pokok pangannya jika mereka memerlukan. Hal ini mengingat dalam aktivitas kegiatan LDPM terdapat usaha pengembangan cadangan pangan untuk tujuan memudahkan petani anggota mengakses pangan, khususnya pada saat paceklik. Melalui pendekatan ini para anggota petani mampu memenuhi kebutuhan hidup yang paling mendasar untuk dapat menjalankan kehidupan sehari-hari menjadi lebih produktif. Disisi lain, diharapkan Gapoktan mampu memberdayakan unit usahanya agar mampu membeli gabah/beras terutama dari hasil produksi petani anggotanya dengan harga yang serendahrendahnya sesuai dengan Harga Pembelian Pemerintah (HPP).

Program Penguatan LDPM dilaksanakan dalam rangka perlindungan dan pemberdayaan petani/kelompok tani/Gapoktan padi dan jagung terhadap jatuhnya harga disaat panen raya dan masalah aksesibilitas pangan disaat paceklik. Kegiatan Penguatan-LDPM dilakukan melalui beberapa tahapan yaitu: Tahap Penumbuhan, Tahap Pengembangan dan Tahap Kemandirian. Dukungan dana Bansos yang bersumber dari APBN pada kegiatan Penguatan-LDPM hanya diberikan kepada Gapoktan Tahap Penumbuhan dan Pengembangan, yaitu pada tahun pertama dan tahun kedua. Sementara itu pada tahun ketiga, Gapoktan hanya akan menerima pembinaan dan/atau bimbingan dari pendamping Tim Teknis Kabupaten/Kota dan Tim Pembina Provinsi.

Modal sosial merupakan komponen penting yang dapat menjadi landasan yang fundamental di dalam menggerakkan interaksi dan komunikasi yang baik antar anggota dalam kelompok maupun antar pengurus dengan anggota kelompoknya. Modal sosial yang baik akan mempengaruhi dinamika organisasi dalam mencapai tujuan-tujuan organisasi dimana modal sosial tersebut akan meningkatkan kohesifitas dan kekompakan anggota kelompok untuk berpartisipasi dalam berbagai kegiatan yang dilakukan oleh kelompok.

Dalam program Penguatan LDPM ini dengan melibatkan kelompok-kelompok tani sehingga tergabung ke dalam Gabungan Kelompok Tani (Gapoktan) ini memberikan peluang kepada Gapoktan untuk menggerakkan seluruh potensi yang dimiliki oleh kelompok, yakni salah satunya adalah adanya modal sosial yang dimiliki oleh seluruh anggota dan pengurus Gapoktan tersebut. Modal sosial yang dapat dilihat adalah adanya kepercayaan antar pengurus dan pengurus dengan anggota kelompok. Jaringan yang dimiliki oleh semua elemen kelompok tani dan norma yang dibangun atas kesadaran dan kemauan bersama untuk memajukan kelompok, baik norma yang sudah ada sebelumnya ditengah-tengah kelompok dan masyarakat maupun norma yang dibuat semenjak program ini mulai dilaksanakan.

Oleh karena itu, perlu untuk diketahui sejauhmana modal sosial yang dimiliki oleh Gapoktan dalam mengimplementasikan program P-LDPM tersebut dalam kegiatan-kegiatannya, baik dari sisi kelompok maupun dari sisi Tim Teknis, Pendamping (PPL) maupun kelompok sasaran (Gapoktan).

\section{TINJAUAN PUSTAKA}

Modal sosial adalah salah satu konsep baru yang digunakan untuk mengukur kualitas hubungan dalam komunitas, organisasi, dan masyarakat. Menurut Putnam modal sosial adalah :

"complexly conceptualized as the network of associations, activities, or relations that bind people together as a community via certain norms and psychological capacities, notably trust, which are essential for civil society and productive of future collective action or goods, in the manner of other forms of capital".

Putnam $(1993,1996,2000)$ menyatakan bahwa modal sosial mengacu pada esensi dari organisasi sosial, seperti trust, norma dan jaringan sosial yang memungkinkan pelaksanaan kegiatan lebih terkoordinasi, dan anggota masyarakat dapat berpartisipasi dan bekerjasama secara efektif dan efisien dalam mencapai tujuan bersama, dan mempengaruhi produktifitas secara individual maupun berkelompok. Sependapat dengan Putnam, Bourdieu (1988) menyatakan bahwa :

"social capital is the aggregate of the actual or potential resources which are linked to possession of a durable network of more or less institutionalized relationships of mutual acquaintance recognition- 
or in other words, to a membership in a group --- which provides each of its members with the backing of the collectivity - owned capital".

Fukuyama (1999) menambahkan norma-norma informal dapat mendorong kerjasama antara dua atau beberapa orang. Norma-norma yang mengandung modal sosial memiliki ruang lingkup yang cukup luas, mulai dari nilai-nilai resiprokal antara teman, sampai dengan yang sangat kompleks dan mengandung nilai-nilai keagamaan.

Berdasarkan definisi tersebut, modal sosial dapat disimpulkan sebagai jaringan dan nilainilai sosial yang dapat memfasilitasi individu dan komunitas untuk mencapai tujuan bersama secara efektif dan efisien. Sebagai suatu istilah, beberapa ahli agak keberatan untuk menggunakan istilah "modal" pada konsep "modal sosial". Alasannya, karena istilah "modal" lebih banyak digunakan untuk pengertian ekonomis, yang menandai pertukaran sosial secara transaksional. Namun, bentuk modal sosial tidak selalu melibatkan pertukaran materiil (Bourdieau, 1986; Kawachi dan Berkman, 2005; Coleman, 1988).

Selanjutnya, Bourdieu menyatakan bahwa : The structure and distribution of the different types and subtypes of capital at a given moment in time represents that immanent structure of the social world, i.e., the set constraints, inscribed in the very reality of the world, which govern its functioning in a durable way, determining the chances of success for practices. Economic theory has allowed to be foisted upon it a definition of the economy practices which is the historical invention of capitalism (1986:242).

Dengan kata lain, "modal" dapat digunakan untuk mendeskripsikan ketersediaan sumberdaya, baik yang terukur maupun tidak terukur, baik yang konkret maupun yang abstrak. Hal ini berarti bahwa modal sosial merupakan salah satu jenis modal. Seperti juga bentuk-bentuk modal lainnya, modal sosial bersifat produktif, yang membuatnya memungkinkan untuk mencapai tujuan tertentu. Misalnya, suatu kelompok yang memiliki kepercayaan yang sangat kuat di kalangan para anggotanya akan dapat mencapai lebih banyak tujuan dibanding kelompok lain yang kurang memiliki kepercayaan di antara para anggotanya. Modal sosial diukur atas dasar (1) generalized trust, (2) norms, (3) reciprocity, dan (4) networks. Generalized trust adalah inti dari modal social. Generalized trust merupakan indikasi dari potensi kesiapan masyarakat untuk bekerjasama satu sama lain.

Kerjasama ini melampaui batasan kekeluargaan dan pertemanan serta batasan persamaan. Dalam arena sosial, generalized trust mempermudah kehidupan dalam masyarakat yang beragam, mendorong perilaku toleransi, dan menerima perbedaan. Sehingga hidup menjadi lebih mudah, lebih bahagia, dan lebih nyaman dengan keberadaan generalized trust dalam masyarakat yang heterogen. Pendapat Putnam, Rothstein dan Stolle diperkuat dengan pendapat Uslaner yang menyatakan bahwa :

"Trust in other people is a key factor in many forms of participation. As trust in others falls, so does participation in civic activities".

Norma-norma, kepercayaan antarpersonal, jejaring sosial, dan organisasi sosial sebagai bentuk modal sosial sangatlah penting tidak hanya bagi masyarakat tapi juga bagi pertumbuhan ekonomi (Coleman, 1988:S96). Sejumlah penelitian yang dilakukan Ben Porath (1980), Oliver Williamson (1975, 1981), Baker (1983) dan Granovetter (1985) (dalam Coleman) mendukung pernyataan Coleman tersebut, bahwa keterkaitan antarorganisasi sosial akan mempengaruhi berfungsinya aktivitas ekonomi.

Trust adalah komponen utama dalam modal sosial, trust memainkan peran penting dalam segala bentuk kegiatan kewarganegaraan serta nilai-nilai moralitas yang mengatur perilaku masyarakat. Dari hasil penelitian Helliwell (2002), Uslaner (2002), Delhey dan Newton (2003) (dalam Rothstein and Uslaner, 2005) pada level mikro, diketahui bahwa pada umumnya orang-orang mempercayai orang-orang lainnya disekitar mereka, dan juga memiliki penilaian yang cukup positif mengenai lembaga-lembaga demokrasi dan pemerintahan, lebih berpartisipasi dalam politik dan dan terlibat aktif pada lembaga-lembaga kemasyarakatan, lebih banyak menyumbang untuk kegiatan sosial, lebih toleran kepada minoritas dan orang-orang yang tidak menyukai mereka, lebih optimistik dalam memandang kehidupan, dan lebih bahagia dengan kehidupannya.

Dari hasil penelitian Putnam (1993), Zak dan Knack (2001), Rothstein dan Stolle (2003) (dalam Rothstein and Uslaner, 2005) pada level meso, diketahui bahwa orang-orang yang memiliki trust, juga memiliki pekerjaan yang lebih baik dalam lembaga-lembaga politik dan pemerintahan, lebih sejahtera dan jarang melakukan kejahatan dan korupsi. Halpern mencatat setidaknya ada sembilan cabang keilmuan yang menggunakan konsep modal sosial dalam pengembangan 
keilmuannya, diantaranya yaitu masalah keluarga dan perilaku remaja, sekolah dan pendidikan, kehidupan komunitas, lingkungan kerja dan organisasi, demokrasi dan pemerintahan, pembangunan ekonomi, kriminologi, dan kesehatan publik.

Dari hasil penelitian Putnam diketahui bahwa perkumpulan arisan tersebar luas di Asia Tenggara. Arisan merupakan salah satu prediktor dari keberadaan trust dalam suatu komunitas. Namun demikian, keberadaan trust dapat mengalami keruntuhan yang disebabkan oleh kemiskinan, korupsi, ketidakadilan ekonomi dan kesempatan.

Woolcock (1998) mengajukan tiga dimensi dari modal sosial, yaitu: bonding, bridging dan linking. Menurut Woolcock, (1) Modal sosial yang bersifat mengikat (bonding social capital) merujuk pada hubungan antarindividu yang berada dalam kelompok primer atau lingkungan ketetanggaan yang saling berdekatan. Komunitas-komunitas yang menunjukkan kohesi internal yang kuat akan lebih mudah dan lancar dalam berbagi pengetahuan. (2) Modal sosial yang bersifat menjembatani (bridging social capital) adalah hubungan yang terjalin di antara orang-orang yang berbeda, termasuk pula orang-orang dari komunitas, budaya, atau latar belakang sosial-ekonomi yang berbeda. Individuindividu dalam komunitas yang mencerminkan dimensi modal sosial yang bersifat menjembatani akan mudah mengumpulkan informasi dan pengetahuan dari lingkungan luar komunitasnya dan tetap memperoleh informasi yang aktual dari luar kelompoknya. Tipe modal sosial ini menunjuk pada hubungan antar individu yang memiliki kekuasaan atau akses pada bisnis dan hubungan sosial melalui kelompok-kelompok sekunder. (3) Modal sosial yang bersifat mengaitkan (linking social capital) memungkinkan individu-individu untuk menggali dan mengelola sumbersumberdaya, ide, informasi, dan pengetahuan dalam suatu komunitas atau kelompok pada level pembentukan dan partisipasi dalam organisasi formal.

\section{METODE PENELITIAN}

\subsection{Ruang Lingkup Penelitian}

Penelitian ini dilaksanakan di Kabupaten Tanjung Jabung Barat yang yaitu Gabungan Kelompok Tani (GAPOKTAN) Sumber Rezeki yang terdapat di desa Teluk Ketapang. Mengingat di desa tersebut merupakan satu lokasi dari dua lokasi dari pelaksanaan program Penguatan - Lembaga Distribusi Pangan Masyarakat (LDPM) yang sudah memasuki tahap Pasca Kemandirian di Kabupaten Tanjung Jabung Barat, maka di desa tersebut dijadikan lokasi penelitian.

Penelitian lapangan akan dilaksanakan selama 60 hari, mulai pada tanggal 1 Oktober 2014 sampai tanggal 30 Nopember 2014. Penelitian ini difokuskan pada pokok kajian mengenai pemanfaatan modal sosial petani dalam implementasi program Penguatan - Lembaga Distribusi Pangan Masyarakat (LDPM) Kabupaten Tanjung Jabung Barat serta peran pemanfaatan modal sosial petani dalam implementasi program Penguatan - Lembaga Distribusi Pangan Masyarakat (LDPM) sebagai potensi dalam penanggulangan kemiskinan di Kabupaten Tanjung Jabung Barat. Kajian pemanfaatan modal sosial yang dimaksud adalah gambaran mengenai tingkat kepercayaan; keberfungsian nilai/norma; keberfungsian jejaring kerja; keberfungsian institusi; dan keberfungsian mekanisme yang berlaku dalam masyarakat sebagai bagian dari modal sosial dalam upaya penanggulangan kemiskinan, yang dimaknai sebagai kondisi ketidakberdayaan yang ditandai dengan lemahnya akses terhadap ekonomi, pendidikan, kesehatan, dan akses untuk mengaktualisasikan diri.

Kajian ini ditinjau dari perspektif Sosiologi dan Pemberdayaan Masyarakat yang berfokus pada identifikasi modal sosial petani yang dimiliki masyarakat serta model-model pemanfaatan modal sosial dalam kerangka pemberdayaan masyarakat agar dapat mengatasi masalah kemiskinan, terutama yang terkait dengan keterbatasan akses terhadap ekonomi, pendidikan, kesehatan, dan aktualisasi diri.

\subsection{Jenis dan Sumber Data}

\subsubsection{Jenis Data}

Untuk memenuhi kebutuhan analisis, ada dua macam data yang dibutuhkan dalam penelitian ini yaitu data primer dan data sekunder.

a. Data primer, yaitu data hasil penelitian yang diperoleh dari hasil wawancara dan pengamatan terhadap perilaku obyek penelitian tentang pemanfaatan modal sosial dalam 
implementasi program Penguatan - Lembaga Distribusi Pangan Masyarakat Kabupaten Tanjung Jabung Barat.

b. Data sekunder, yaitu data yang diperoleh dari sumber yang telah mengolahnya meliputi sumber-sumber peraturan dan konsep mengenai modal sosial dan program Penguatan Lembaga Distribusi Pangan Masyarakat di Kabupaten Tanjung Jabung Barat.

\subsubsection{Sumber Data}

Sumber data yang digunakan dalam penellitian ini sebagai berikut :

a. Data Primer yaitu data yang diperoleh dari para informan yaitu Kepala Kantor Ketahanan Pangan Kabupaten Tanjung Jabung Barat, Kepala Bidang yang berkaitan dengan aspek penelitian, Penyuluh Pertanian Lapangan (PPL), Aparat Pemerintahan Desa (Kepala Desa, Ketua RT/RW), Ketua Gapoktan, Anggota Gapoktan, Tokoh Masyarakat, Tokoh Agama, Tokoh Adat dan Tokoh Pemuda.

b. Data Sekunder bersumber dari literatur, laporan, buku serta dokumen yang mendukung penelitian ini yang diperoleh dari Badan Ketahanan Pangan Propinsi Jambi, BAPPEDA Kabupaten Tanjung Jabung Barat, Kantor Ketahanan Pangan Kabupaten Tanjung Jabung Barat, Kantor Badan Pusat Statistik (BPS) Kabupaten Tanjung Jabung Barat.

\subsection{Metode Pengumpulan Data}

Lofland dan Lofland (1984) menyebutkan bahwa pengumpulan data dalam suatu rangkaian penelitian kualitatif terdiri atas tiga kegiatan, sebagai berikut :

a. Getting in, yaitu tahap persiapan penyusunan pedoman wawancara, persiapan pelaksanaan wawancara dan observasi serta proses memasuki lokasi penelitian yaitu peneliti memasuki daerah penelitian dengan membawa surat ijin dari pihak yang berwenang.

b. Getting along, yaitu tahap pelaksanaan wawancara dan observasi untuk mendapatkan data yang diperlukan sebanyak mungkin. Ketika berada di lokasi penelitian mencari informasi yang dibutuhkan secara lengkap dan berupaya menangkap makna berdasarkan informasi dan pengamatan yang diperoleh. Pada tahap kedua ini peneliti berusaha menjalin hubungan dengan subjek penelitian.

c. Getting out, merupakan tahap akhir dimana data yang diperoleh sudah jenuh kemudian dilakukan tahap pengumpulan data (logging the data).

Pengumpulan data dalam penelitian ini dilakukan melalui :

3.3.1 Wawancara mendalam (in-depth interview). Wawancara dilakukan terhadap Kepala Kantor Ketahanan Pangan Kabupaten Tanjung Jabung Barat dan Kepala Bidang yang berkaitan dengan aspek penelitian, pengurus Gapoktan, anggota Gapoktan, tokoh masyarakat, tokoh agama, tokoh adat dan tokoh pemuda serta Aparat Pemerintahan Desa (Kepala Desa dan Ketua RT/RW). Data yang digali dari wawancara ini terutama berkaitan dengan bagaimana implementasi pemanfaatan modal sosial dilaksanakan. Dilakukan dengan memberikan penjelasan dari informan berkenaan dengan isi dan maksud sejumlah pertanyaan tertentu melalui wawancara bebas dan terstruktur. Menurut Djaali (2003: 104) wawancara mendalam adalah suatu teknik wawancara yang didasarkan oleh rasa skeptis yang tinggi, sehingga wawancara mendalam banyak diwarnai probing. Pra kondisi dari wawancara mendalam adalah kedekatan atau keakraban hubungan antara pewawancara dengan yang diwawancarai serta tingkat pemahaman pewawancara terhadap keinginan, persepsi, dan prinsip dari responden.

3.3.2 Observasi. Mengamati secara langsung fenomena yang berhubungan dengan aspek penelitian guna melengkapi data primer yang diperoleh melalui wawancara. Teknik pengumpulan data dengan cara observasi menurut Burhan Bungin (2007: 115) adalah metode pengumpulan data yang digunakan untuk menghimpun data penelitian melalui pengamatan dan penginderaan. Suatu kegiatan pengamatan baru dikategorikan sebagai kegiatan pengumpulan data penelitian apabila memiliki kriteria, sebagai berikut : telah direncanakan secara serius, harus berkaitan dengan tujuan yang telah ditetapkan, dicatat secara sistematik dan dihubungkan dengan proporsi umum, dan pengamatan dapat dicek/dikontrol mengenai keabsahannya.

3.3.3 Studi Kepustakaan. Dilakukan dengan cara melihat dan mempelajari berbagai bahan bacaan dan peraturan yang erat kaitannya dengan pemanfaatan modal sosial dan program PenguatanLembaga Distribusi Pangan Masyarakat (P-LDPM). 


\subsection{Kisi - Kisi Penelitian}

Kisi-kisi Penelitian digunakan sebagai panduan atau pedoman di dalam melakukan penelitian agar supaya penelitian ini tetap berada pada jalur yang semestinya sesuai dengan fokus penelitian yang telah ditetapkan. Kisi-kisi penelitian juga dimaksudkan untuk mempermudah dan memberikan arahan yang lebih jelas dalam pencapaian tujuan penelitian. Adapun kisi-kisi penelitian adalah sebagai berikut:

Tabel 1. Tabel Kisi- Kisi Penelitian

\begin{tabular}{|c|c|c|c|}
\hline $\begin{array}{c}\text { Fokus } \\
\text { Penelitia } \\
\text { n }\end{array}$ & Dimensi & Tema & Arah Pertanyaan \\
\hline $\begin{array}{l}\text { Modal } \\
\text { Sosial }\end{array}$ & $\begin{array}{l}\text { Jaringan } \\
\text { ( Robert } \\
\text { D Putnam ) }\end{array}$ & $\begin{array}{l}\text { - Jejaring kerja } \\
\text { - Informasi dan } \\
\text { Komunikasi } \\
\text { - Pemberdayaan } \\
\text { dan tindakan } \\
\text { politik }\end{array}$ & $\begin{array}{l}\text { - Bagaimana terbentuknya hubungan saling } \\
\text { percaya diantara anggota di dalam pengurus } \\
\text { dan anggota Gapoktan serta dengan } \\
\text { implementor. } \\
\text { - Sejauhmana rasa kepedulian antar anggota di } \\
\text { dalam kelompok sasaran. } \\
\text { Bagaimana rasa kebersamaan yang tinggi dan } \\
\text { kekompakan anggota dan pengurus } \\
\text { Gapoktan. } \\
\text { Apakah di dalam kelompok sasaran memiliki } \\
\text { kegiatan bersama. } \\
\text { Apakah terdapat hubungan kerjasama yang } \\
\text { baik diantara pengurus dan anggota serta } \\
\text { dengan implementor. } \\
\text { Apakah anggota di dalam kelompok sasaran } \\
\text { memiliki aktifitas di dalam kelompok- } \\
\text { kelompok lain diluar Gapoktan. } \\
\text { Apakah pengurus dan implementor memiliki } \\
\text { jaringan kerja baik horizontal maupun } \\
\text { vertikal. } \\
\text { Apakah kelompok sasaran memperoleh akses } \\
\text { informasi dan komunikasi dengan baik. } \\
\text { Apakah kelompok sasaran memiliki } \\
\text { kemampuan untuk mengambil keputusan } \\
\text { didalam menjalankan usaha Gapoktan. }\end{array}$ \\
\hline $\begin{array}{l}\text { Implemen } \\
\text { tasi } \\
\text { Program } \\
\text { P-LDPM }\end{array}$ & $\begin{array}{l}\text { Komunik } \\
\text { asi }\end{array}$ & $\begin{array}{l}\text { - Sosialisasi } \\
\text { Kabijakan } \\
\text { a. Staf } \\
\text { b.informasi } \\
\text { c.Wewenang } \\
\text { d.Fasilitas }\end{array}$ & $\begin{array}{l}\text { - Apakah implementor dapat memahami tugas } \\
\text { dengan jelas. } \\
\text { - Apa transmisi/saluran komunikasi yang } \\
\text { digunakan di dalam implementasi kebijakan. } \\
\text { - Apakah terdapat konsistensi di dalam uraian } \\
\text { tugas yang diemban implementor. } \\
\text { - Apakah program P-LDPM } \\
\text { disosialisasikan dengan baik. } \\
\text { - Apakah implementor memiliki personal yang } \\
\text { cukup dan mampu untuk menjalankan tugas. } \\
\text { - Apakah implementor memperoleh informasi } \\
\text { tentang program dengan baik. } \\
\text { - Sejauhmana implementor memiliki } \\
\text { kewenangan yang cukup di dalam } \\
\text { menjalankan tugas. } \\
\text { - Apa sajakah fasilitas yang diperoleh oleh }\end{array}$ \\
\hline
\end{tabular}




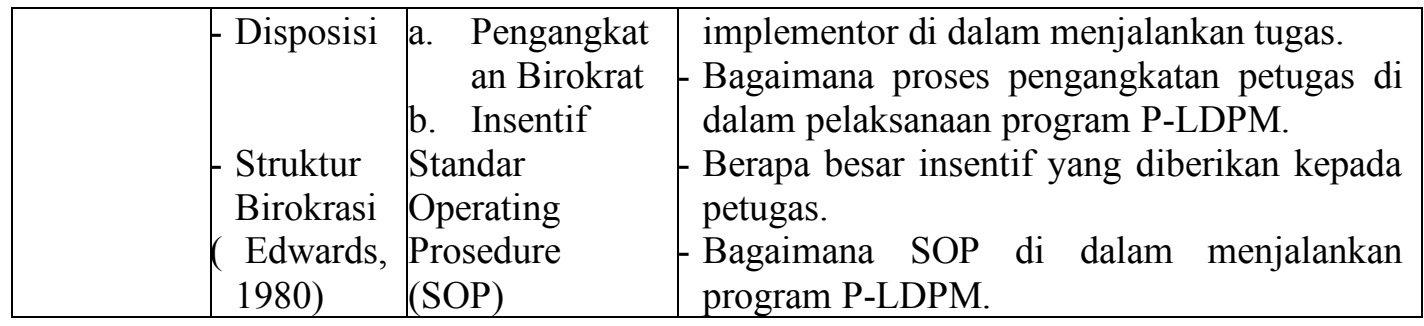

\subsection{Metode Analisis Data}

Untuk memeriksa keabsahan data yang diperoleh di lapangan maka dapat digunakan teknik triangulasi, yaitu memanfaatkan sesuatu yang lain di luar data itu untuk keperluan pengecekan atau sebagai pembanding terhadap data tersebut. Dalam laporan ini, triangulasi data hasil penelitian dilakukan pada sumber penyelidikan dan teori. Triangulasi penyelidikan dilakukan dengan cara membandingkan informasi yang di depan umum dengan apa yang dikatakan secara pribadi, atau membandingkan informasi dari perspektif lain mengenai hal yang sama. Triangulasi bisa juga dilakukan melalui diskusi dengan orang yang berbeda pandangan tentang hal yang sama.

Triangulasi teori dapat dilakukan dengan mencermati teori yang digunakan, kemudian membandingkan hasil yang diperoleh dengan teori lainnya. Di samping itu, trianggulasi bisa dilakukan melalui logika, yaitu cara untuk melihat kemungkinan yang muncul dari analisis, didukung oleh data yang ditemukan di lapangan. Semua data yang telah terkumpul direduksi, dideteksi dengan prosedur yang telah diungkapkan sebelumnya dan dari sini akan dapat ditarik suatu kesimpulan.

Metode penelitian yang digunakan adalah dengan menggunakan metode penelitian kualitatif, dan dengan menggunakan pedoman atau kisi-kisi wawancara langsung. Pengambilan data menggunakan wawancara secara mendalam dan pengamatan lapangan.

Dalam pengumpulan data/informasi di lapangan, penelitian ini juga menggunakan teknik bola salju (snowball). Teknik ini digunakan ketika informan merekomendasikan untuk mewawancarai informan lainnya (diluar informan yang sudah ditetapkan) yang dinilai dapat memberikan informasi tambahan dan/atau informan dimaksud memiliki data/informasi yang lebih lengkap dan akurat.

Data-data dan informasi yang diperoleh dianalisis dengan menggunakan model Spradley. Spradley (1980), diacu dalam Sugiyanto (2007:253) membagi analisis data dalam penelitian kualitatif berdasarkan tahapan dalam penelitian kualitatif. Tahapan penelitian kualitatif menurut Spradley ditunjukkan pada gambar 2 .

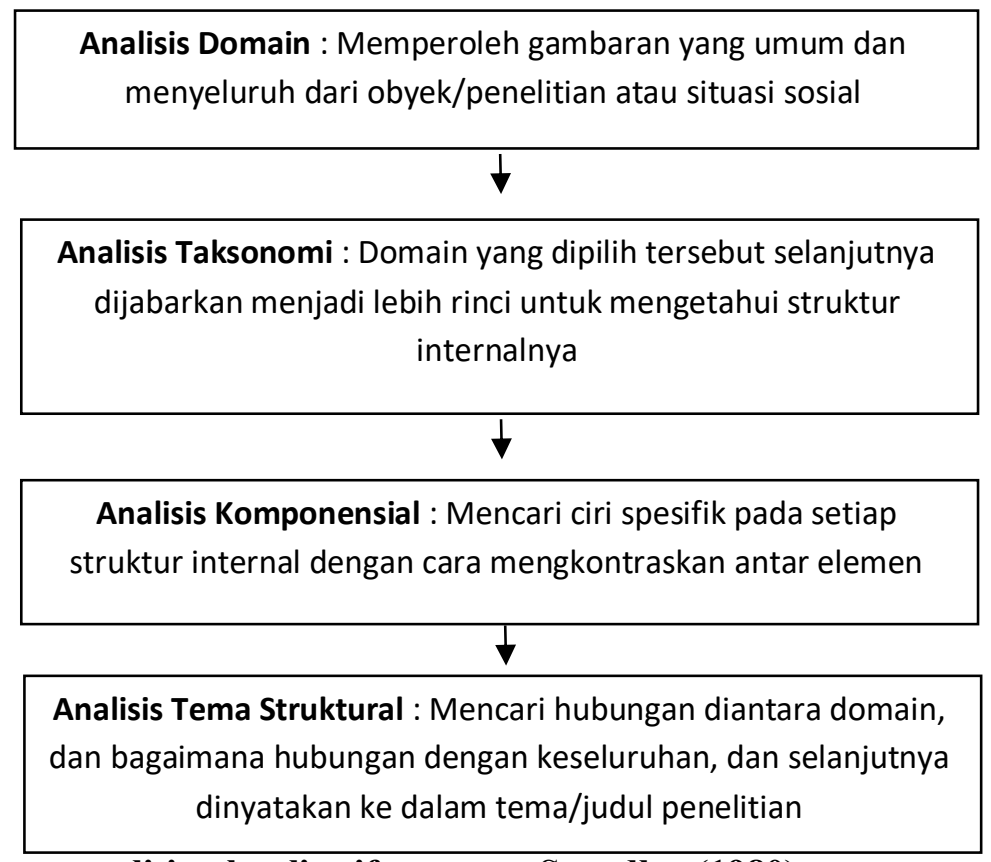

Gambar 2. Tahapan penelitian kualitatif menurut Spradley (1980). 


\section{PEMBAHASAN}

Dalam penelitian diperoleh berbagai informasi terhadap berbagai kategori komponen yang ditelliti secara kualitatif terutama dalam keterkaitan antara modal sosial yang dimiliki masyarakat petani di beberapa kelompok Gapoktan (Gabungan kelompok tani) yang ada di Kabupaten Tanjung Jabung Barat dengan kategori atau komponen teori implementasi kebijakan menurut Edwar III dalam program penguatan-LDPM (Lembaga Distribusi Pangan Masyarakat).

Dari hasil penelitian, terdapat beberapa modal sosial yang teridentifikasi di dalam kelompok Gapoktan dalam Gabungan Kelompok Tani (GAPOKTAN) Sumber Rezeki yang terdapat di desa Teluk Ketapang. Modal sosial yang dimiliki pada Gapoktan tersebut diketahui cukup kuat, baik trust yang terdapat diantara hubungan antar sesama anggota maupun terdapat didalam hubungan dengan kepengurusan Gapoktan.

Di dalam penelitian ini, titik fokusnya adalah implementasi di dalam kegiatan pendampingan yang di lakukan implementor yaitu Tim Teknis Kabupaten yaitu Kantor Ketahanan Pangan, Pendamping dalam hal ini adalah Penyuluh Pertanian Lapangan yang ditunjuk dan Kelompok Sasaran yaitu pengurus dan anggota Gapoktan.

Kegiatan pendampingan terdiri dari kegiatan yang dilakukan Gapoktan pada tahap pasca kemandirian yaitu baik dalam menjalankan usaha Gapoktan sesuai dengan unit usahanya yaitu pengolahan, penyimpanan dan pembelian/penjualan gabah dan koordinasi dalam pelaporan Gapoktan secara rutin.

\subsection{Tim Teknis Kabupaten}

Komposisi Tim Teknis Kabupaten sesuai dengan SK Bupati No 282 Tahun 2009 tentang penetapan Tim Teknis Kabupaten dengan memanfaatkan sumberdaya yang berada dalam naungan Badan Ketahanan Pangan Kabupaten yakni yang diketuai oleh Kepala Badan Ketahanan Pangan Kabupaten Tanjung Jabung Barat dan tiga orang adalah Kasi sebagai sekretaris dan anggota dan Subag TU dan staf, serta hanya satu orang yang terdiri dari Bagian Administrasi Perekonomian Setda Kabupaten.

Sesuai dengan Surat Keputusan tersebut, tugas Tim Teknis diantaranya adalah melakukan koordinasi teknis operasional dengan instansi terkait, melakukan pemantauan dan pembinaan dalam meningkatkan kinerja, bersama-sama dengan Tim Teknis Propinsi Jambi melaksanakan identifikasi dan verifikasi terhadap calon Gapoktan penerima program P-LDPM .

Komunikasi merupakan hal yang turut berpengaruh dalam pelaksanaan program Penguatan Lembaga Distribusi Pangan Masyarakat (LDPM). Sikap masyarakat yang cukup mengetahui hal-hal terkait program P-LDPM dan ketentuan-ketentuannya, terutama tentang bantuan dana dan pendampingan yang dilakukan, hal ini terdapat komunikasi yang cukup baik dilakukan oleh pelaksana program yaitu oleh Kantor Ketahanan Pangan Kabupaten Tanjung Jabung Barat dan Penyuluh Pertanian Lapangan kepada kelompok sasaran atau pengurus Gapoktan.

Komunikasi antara pelaksana program dengan kelompok sasaran program yaitu anggota Gapoktan dalam hal seputar bantuan dana sangat diperlukan terutama dari segi jumlah dana, alokasi dana, maksud dan tujuan, manfaat dari alokasi dana bantuan sampai pada tata cara atau mekanisme penggunaan dana tersebut harus dapat dikomunikasi dengan baik dari pelaksana kepada para anggota Gapoktan. Artinya anggota Gapoktan dituntut untuk mengetahui lebih jelas dan paham tentang hal-hal yang berkaitan dengan bantuan dana tersebut.

Dalam hal komunikasi terjadi cukup baik dapat antara implementor dengan pengurus Gapoktan khususnya, hal ini diketahui dari hasil wawancara dengan bapak Sageyanto sebagai pihak Tim Teknis Kabupaten mengakui adanya pengurus khususnya ketua Gapoktan yang proaktif didalam menjalan usaha Gapoktan melalui program P-LDPM tersebut. Terutama dalam hal berkoordinasi dan bekerjasama di dalam 'usaha jemput bola' oleh ketua Gapoktan berkoordinasi dengan pihak implementor di kabupaten walaupun jarak tempuh menuju ibu kota kabupaten cukup jauh yang bisa mencapai waktu kurang lebih tiga jam untuk jalur darat dan kurang lebih dua jam untuk jalur sungai tetapi jalur sungai hanya bisa dilalui untuk satu hari terdapat satu jadwal pulang pergi. Sedangkan dengan jalur darat terdapat jalan yang sangat sulit untuk dilalui, apalagi pada musim hujan karena sebahagian badan jalan yang harus dilalui mengalami rusak berat dengan kondisi yang berlubanglubang dengan tekstur tanah yang lembut. 
Letak yang cukup sulit dari jangkauan kantor Tim Teknis Kabupaten tersebut memang akan menjadi hambatan di dalam melakukan koordinasi dan komunikasi secara langsung dengan pihak kelompok sasaran atau pengurus Gapoktan. Faktor geografis tersebut mengharuskan adanya upaya yang maksimal bagi pihak Tim Teknis dalam melakukan sosialisasi dan koordinasi dalam menjalankan kegiatan Gapoktan. Namun, secara rutinitas telah dilakukan pertemuan secara periodik sebulan sekali antara Tim Teknis Kabupaten dengan seluruh pengurus Gapoktan yang menerima program P-LDPM tersebut diantaranya adalah Gapoktan Sumber Rezeki.

Namun, walaupun terdapat sedikit hambatan di dalam melakukan hubungan secara langsung antara Tim Teknis Kabupaten dengan Pengurus Gapoktan, pemanfaatan fasilitas telepon selular atau hp (handphone) sudah dapat digunakan, walaupun signalnya hanya terdapat pada tempat-tempat tertentu saja, tetapi komunikasi lewat hp ini sering dimanfaatkan oleh Tim Teknis di dalam berkoordinasi dan berkomunikasi dengan pengurus tentang pelaksanaan program.

Menurut Bapak Sageyanto, Bapak Kasrun sebagai ketua Gapoktan Sumber Rezeki dikenal rajin dan sangat aktif di dalam melakukan koordinasi dan evaluasi yang dilaksanakan di kantor Tim Teknis yakni di kantor Ketahanan Pangan Kabupaten di Kota Kuala Tungkal tersebut. Di samping itu, Bapak Kasrun juga terlihat serius dalam menjalankan aktivitas kelompok Gapoktan. Bahkan, untuk beras yang merupakan hasil olahan atau penggilingan Gapoktan telah berhasil di buatkan nama hak paten dengan nama beras "Pondok Kelapa" dengan varietas RS dengan label beras bermutu yang diproduksi oleh Ketapang Jaya Kabupaten Tanjung Jabung Barat.

Dalam menjalankan tugasnya sebagai pelaksana dan pembina program P-LDPM tersebut maka Tim Teknis kabupaten telah menjalin hubungan yang sangat intensif dengan pengurus Gapoktan yaitu dengan Bapak Kasrun. Bapak Kasrun merupakan tokoh masyarakat desa Sungai Ketapang dengan segudang pengalaman yang juga sudah dikenal lama oleh sebagian Tim Teknis karena Bapak Kasrun sudah pernah beberapa kali melakukan kerjasama dengannya dalam kegiatan yang lain seperti dalam mengerjakan jalan usahatani dan irigasi bantuan dari Kantor Ketahanan Pangan pada tahun-tahun sebelumnya.

Kemampuan dengan keseriusan yang dimiliki oleh Bapak Kasrun sebagai ketua Gapoktan dalam mengelola Gapoktan juga dirasakan oleh warga anggota Gapoktan itu sendiri, yang sudah bertahun-tahun dipandang masyarakat sebagi tokoh yang dianggap oleh warganya bisa membantu warganya di dalam menghadapi berbagai masalah yang dihadapi di dalam hidup sehari-hari baik masalah pembangunan dan kesediaannya untuk membantu warganya yang membutuhkan bantuan.

Dengan demikian, dalam komunikasi implementasi program menjadi lebih lancar baik secara vertikal dengan Tim Teknis Kabupaten maupun komunikasi secara horizontal sesama warga anggota Gapoktan.

Namun, disisi lain besarnya keberadaan peranan bapak Kasrun sebagai ketua gapoktan di dalam gapoktan juga menjadikan gapoktan tidak bisa mandiri secara kelompok dan semakin meningkatkan adanya ketergantungan kepada figur bapak Kasrun tersebut. Kondisi demikian sangat kurang baik bagi perkembangan kelompok dan pemberdayaan anggotanya dikemudian hari sehingga komunikasi dan informasi dalam implementasi program ini lebih dimonopoli oleh satu orang saja dan anggota dan pengurus gapoktan yang lain cenderung pasif dan manut saja.

Kondisi demikian terjadi juga dipengaruhi oleh adanya budaya paternalistik yang ada pada masyarakat di gapoktan Sumber Rezeki ini, hal ini dapat terlihat adanya budaya di dalam gapoktan tersebut dimana pengurus lainnya di bawah masih memiliki rasa sungkan terhadap atasannya untuk mengungkapkan apa yang menjadi pikiran, gagasan dan ide mereka meskipun ketua tersebut tahu bahwa hal itu lebih baik dari pada sekedar menuruti perintah atasan mereka. Hal ini dapat dikatakan bahwa budaya paternalistik yang cukup kuat cenderung akan menghambat partisipasi dan dapat menurunkan kinerja pengurus dan manajerial gapoktan secara keseluruhan.

Budaya merupakan keseluruhan pola pemikiran, perasaan dan tindakan dari suatu kelompok sosial, yang membedakan dengan kelompok sosial yang lain. Budaya organisasi merupakan seperangkat nilai, norma, persepsi dan pola perilaku yang dibuat atau dikembangkan dalam suatu organisasi dengan maksud untuk dapat mengatasi masalah-masalah yang timbul, apakah masalah yang terkait dengan adaptasi secara eksternal atau masalah integrasi secara internal.

Gultom (1994, dalam Kurnia 2004) Budaya manajemen ada tiga tipe yaitu, pertama manajemen autokratik dimana atasan selalu meberikan pengarahan dan cenderung memaksakan kehendak, dan perilakunya cenderung tidak mau di kritik. Kedua manajemen paternalistik dimana atasan berperan 
sebagai "bapak" yang dianggap lebih tahu akan segala hal. Kondisi ini menyebabkan bawahan merasa "tidak" enak jika menyampaikan usulan apalagi mengkritik kesalahan atasannya.

Tipe manajemen seperti ini akan mengurangi inisiatif bawahan. Budaya seperti ini akan mengurangi bahkan menghambat inisiatif dari bawahan. Ketiga manajemen demokratis yaitu atasan mengutamakan kerjasama dengan sesama anggota organisasi, dan adanya kesamaan derajat antara atasan dan bawahan. Manajemen demokratis akan mendorong para bawahan untuk memberikan masukan, saran, bahkan kritik pada kebijakan yang diambil oleh atasan.

Di samping itu, dalam implementasi program P-LDPM tersebut terdapat aktor lain sebagai pendamping yaitu adanya pihak PPL yang berada di lapangan yang akan mendampingi Gapoktan secara teknis lapangan baik menyangkut teknis operasional maupun teknis pelaporan serta adminitrasi keuangan Gapoktan.

Sesuai dengan Pedoman Pelaksanaan Program P-LDPM Tahun 2012, di dalamnya disebutkan dua tugas dan tanggung jawab pokok pendamping yaitu; pertama, rencana/jadwal dan materi pendampingan yang akan dilaksanakan untuk membimbing Gapoktan baik dalam hal cara menyusun rencana usaha, cara membuata pembukuan keuangan, cara membuat usulan penggunaan dana bansos, cara menghitung kebutuhan cadangan pangan, cara menetapkan harga dan volume pembelian gabah, cara membuat aturan dan sangsi, dan cara mengembangkan unit-unit usaha gapoktan. Kedua, laporan hasil pendampingan/pembinaan ke Gapoktan kepada Tim Teknis Kabupaten dalam hal perkembangan dalam membuat rencana usaha gapoktan, perkembangan dalam membuat pembukuan kegiatan, perkembangan dalam membuat usulan penggunaan dana bansos, perkembangan kemampuan kelompok dalam menghitung kebutuhan cadangan pangan, perkembangan gapoktan dalam membuat dan menerapkan aturan dan sanksi, perkembangan gapoktan dalam membuka jejaring pemasaran, perkembangan pembelian gabah dan langkah-langkah pemecahan masalah yang dihadapi oleh gapoktan.

Dalam implementasi tugas dan tanggung jawab PPL kepada Gapoktan maka harus tercipta hubungan dan kerjasama yang baik terutama antara PPL dengan pengurus Gapoktan. Agar terbentuknya kerjasama yang baik diperlukan adanya hubungan saling percaya diantara keduanya.

Seperti yang telah diuraikan di atas, bahwa PPL tersebut merupakan warga desa Teluk Ketapang itu sendiri sehingga secara lebih dalam PPL dapat mengenali para pengurus dan anggota dengan baik sehingga dalam proses komunikasi menjadi lebih mudah baik terutama tentang sejauhmana anggota Gapoktan dapat mengetahui dan memahami tugas dan fungsi dari PPL sebagai pendamping di dalam program tersebut. Hal ini dapat dilihat dari sejauh mana anggota Gapoktan dapat memanfaatkan para pendamping di dalam mendapatkan informasi baik melalui formal maupun secara tidak formal.

Dalam menjalankan program P-LDPM ini diperlukan program pendampingan yang dilakukan oleh Penyuluh Pertanian Lapangan selama program ini berjalan. Dalam hal komunikasi baik dalam tahapan sosialisasi maupun dalam proses pelaksanaan program ini diperlukan adanya komunikasi yang memanfaatkan modal sosial petani anggota Gapoktan tersebut.

Adapun modal sosial yang dimanfaatkan diantaranya adalah modal trust yang kuat di dalam kelompok Gapoktan. Komunikasi terutama menyangkut pelaksanaan program dilakukan dengan memanfaatkan peran tokoh-tokoh masyarakat dan pengurus Gapoktan yang ada. Nilai trust yang tinggi tersebut menyebabkan proses komunikasi berjalan lancar dengan mendapat respon yang cukup baik dari anggota Gapoktan yang ada. Trust yang tinggi disebabkan adanya karakter yang kuat yang dimiliki oleh sebagian besar tokoh masyarakat dan para pengurus Gapoktan. Di samping itu, adanya homogenitas asal daerah antara anggota dan pengurus dan para tokoh masyarakat tersebut telah menyebabkan adanya rasa memiliki dan tanggung jawab serta solidaritas yang tinggi dari pengurus dan tokoh masyarakat desa tersebut.

\subsection{Pendamping (PPL)}

Pendamping dalam program P-LDPM untuk Gapoktan Sumber Rezeki ini pada awalnya mulai tahun 2009 di tangani oleh dua orang PPL yaitu bapak Maman PPL desa Senyerang dan bapak Sahrum PPL desa Bram Itam Kiri, dan semenjak kurang lebih enam bulan yang lalu pendampingnya sudah mengalami pergantian dimana penggantinya sekarang adalah ibu Lilis yang merupakan PPL desa Teluk Ketapang yang merupakan warga asli desa Teluk Ketapang. 
Dalam komunikasi bahwa Ibu Lilis sebagai PPL memiliki kepercayaan yang lebih kuat karena Ibu Lilis merupakan warga desa asli Teluk Ketapang sehingga dalam melakukan komunikasi berbagai hal tentang program terutama di dalam pendampingan menjalankan usaha Gapoktan dan dalam melakukan pelaporan mingguan dan bulanan dengan pengurus Gapoktan akan memiliki kemudahan di dalam praktek komunikasi dan dapat menghindari adanya bias di dalam komunikasi. Begitu juga sebaliknya, kepercayaan yang dimiliki oleh Ibu Lilis terhadap pengurus Gapoktan dalam hal komunikasi juga akan semakin dapat meminimalisir adanya distorsi dan miskomunikasi diantara PPL dan pengurus Gapoktan karena adanya latar belakang sosial budaya yang sama.

Di samping itu, komunikasi tentang kegiatan Gapoktan bisa tidak hanya dilakukan secara formal tetapi juga bisa dilakukan secara informal dalam waktu-waktu luang dan santai serta dalam waktu kegiatan-kegiatan yang ada di desa dengan pengurus dan anggota Gapoktan.

Komunikasi yang efektif juga dapat menjangkau kepada semua stakeholder yang ada di desa dan bahkan warga masyarakat tentang program yang sudah dan sedang berjalan. Kepercayaan yang kuat akan semakin membentuk adanya hubungan yang harmonis diantara PPL dan pengurus Gapoktan. Namun, kepercayaan yang terjadi haruslah bersifat positif yang selaras dengan upaya untuk mencapai tujuan program P-LDPM tersebut sesuai dengan petunjuk pelaksanaan program.

Dalam kehidupan sehari-hari setiap anggota masyarakat selalu terikat ke dalam proses dan mekanisme sosial yang di dalamnya terdapat berbagai aturan kebiasaan yang ada di tengah-tengah masyarakat. Aturan kebiasaan itu telah mengatur berbagai bentuk dan pola hubungan antar anggota masyarakat itu sendiri yang disebut dengan norma-norma masyarakat.

Norma masyarakat yang ada tentu membentuk karakter dan budaya masyarakat yang ada baik itu karakter masyarakat yang baik, jujur dan pekerja keras. Budaya kerja dan solidaritas dengan sesama yang tinggi juga dapat ditentukan oleh norma itu sendiri.

Berdasarkan hasil penelitian ditemukan berbagai norma sosial dan norma agama yang ada di tengahtengah masyarakat Desa Teluk Ketapang tersebut terutama norma yang dimiliki oleh Gapoktan Sumber Rezeki ini, yakni diantaranya terdapatnya norma sosial yang suka tolong menolong atau hidup bergotong royong. Hal ini terbukti dengan adanya sistem Kerja Arian (Gantian) dilakukan di Gapoktan Sumber Rezeki desa Teluk Ketapang. Sistem Kerja Arian ini merupakan sistem kerja gotong royong secara bergantian dari lokasi areal sawah anggota Gapoktan yang satu ke areal sawah anggota Gapoktan yang lain yang dilakukan mulai pada musim tanam maupun pada kegiatan panen. Kegiatan ini wajib dikuti oleh semua anggota kelompok tani yang ada, dan jika tidak dikuti akan dikenakan sangsi sosial dan akan diberi himbauan dan teguran oleh pengurus Gapoktan.

Pada Gapoktan Sumber Rezeki terdapat beberapa norma yang dijumpai yang pada umumnya merupakan norma positif yang bersumber dari aturan adat masyarakat setempat. Norma yang ada tersebut diantaranya adalah norma hidup bersih dan sehat dimana setiap jum'at pagi anggota masyarakat melaksanakan kegiatan jum'at bersih dengan melakukan gotong royong di seluruh wilayah desa. Di samping itu terdapat norma hidup rukun dan spiritual masyarakat dimana anggota masyarakat melaksanakan berbagai kegiatan baik kegiatan keagamaan berupa kegiatan yasinan RT dan pengajian ibu-ibu Majelis Taqlim. Di samping itu juga anggota masyarakatnya terlibat di dalam saling bantu-membantu dalam melaksanakan hajatan oleh anggota masyarakat yang dilakukan secara bergantian.

Melihat berbagai norma positif yang dimiliki oleh anggota Gapoktan tersebut maka dalam pelaksanaan komunikasi dapat dilakukan dengan memanfaatkan berbagai kegiatan masyarakat baik melalui kegiatan keagamaan maupun dalam kegiatan lainnya.

Komunikasi yang diterapkan oleh pelaksana dan pendamping program P-LDPM tersebut dilakukan melalui penerapan komunikasi dalam kelompok secara efektif, tidak hanya melalui kelompok Gapoktan saja tetapi juga di dalam kegiatan masyarakat lainnya.

Norma adat ketimuran yang kental terutama di dalam tata krama di dalam berkomunikasi juga menjadi faktor mudahnya proses komunikasi dimulai dengan adanya respon awal yang baik sehingga para pelaksana dan pendamping merasa lebih nyaman dan lancar di dalam melakukan berbagai komunikasi dalam menjalankan program P-LDPM ini.

Keikutsertaan anggota yang tinggi adalah suatu respon yang nyata oleh anggota masyarakat khususnya anggota petani sehingga organisasi Gapoktan ini dapat berjalan dengan baik dan lancar, dan pada akhirnya Gapoktan ini merupakan Gapoktan yang cukup berhasil di dalam pelaksanaan program tersebut. 
Di samping norma sosial, terdapat juga norma keagamaan atau keyakinan kepada sang Khalik yang Maha Kuasa, dimana pada masyarakat desa Teluk Kepayang ini memiliki mayoritas penduduk beragama Islam dengan fanatisme yang tinggi. Norma Agama secara umum terlihat dari adanya nilainilai islami yang berkembang di dalam masyarakat seperti adanya ketaatan dalam beribadah, kerukunan atau saling menghargai diantara anggota masyarakat, kejujuran dan cenderung berbuat kebajikan yang suka saling tolong-menolong yang merupakan sebagai pintu amal bagi anggota masyarakatnya.

Dalam implementasi program P-LDPM tersebut, norma-norma yang dimiliki oleh masyarakat desa Teluk Kepayang ini sangat mendukung terbinanya komunikasi yang baik yang bisa dimanfaatkan baik oleh PPL sebagai pendamping program dengan pengurus dan anggota Gapoktan, maupun antara pengurus dengan anggota serta dengan sesama anggota Gapoktan.

Secara kolektif nilai-nilai yang berkembang tersebut dapat dilihat dalam adanya kegiatan Kenduri Nyimah Parit (Hari ulang tahun) yang merupakan kenduri tolak balak, yang dapat dimanfaatkan untuk mengevaluasi kinerja masyarakat dengan swadaya, seperti pembagunan jalan setapak, pembangunan mesjid, jembatan dan lain-lain. Hal ini termasuk kegiatan pelaksanaan program P-LDPM ini.

Di dalam pendampingan program P-LDPM tersebut, PPL sebagai pendamping teknis di dalam kegiatan tersebut dapat melaksanakan kegiatan untuk membimbing dan mengarahkan Gapoktan agar dapat berjalan dengan baik dan lancar sesuai dengan capaian target dan sasaran program, serta melakukan fungsi dalam memberikan informasi-informasi yang berguna bagi pelaksanaan program dan mengkoordinasikan antara Gapoktan dengan pihak penanggungjawab program tingkat Kabupaten yaitu dengan pihak Kantor Ketahanan Pangan Kabupaten Tanjung Jabung Barat. Dengan adanya norma-norma yang melekat di dalam masyarakat desa Teluk Kepayang tersebut menjadi sangat menguntungkan bagi PPL dalam melakukan komunikasi, dalam memberikan informasi, serta dalam berkoordinasi. Apalagi PPL yang mendampingi yakni Ibu Lilis tersebut merupakan berasal dari masyarakat asli desa Teluk Ketapang, sehingga norma yang ada sangat mendukung di dalam implementasi program terutama di dalam memanfaatkan saluran-saluran komunikasi yang tersedia di dalam masyarakat baik secara formal maupun secara informal dengan intensitas komunikasi yang tinggi.

Staf pelaksana program terdapat struktur yang jelas melalui Kantor Ketahanan Pangan Kabupaten Tanjung Jabung Barat beserta dengan para PPL (Penyuluh Pertanian Lapangan), dimana pihak kantor dalam hal perencanaan, pelaksanaan, monitoring dan evaluasi sampai pelaporan sedangkan PPL adalah sebagai pendamping secara teknis di lapangan.

Begitu juga dengan juklak dan juknis sebagai panduan pelaksanaan dan teknis di lapangan agar implementor di dalam menajalankan tugas dan fungsi dapat tepat sasaran dan sesuai dengan target yang diinginkan dan sesuai dengan norma-norma yang mengikat anggota masyarakat tersebut. PPL Pendamping ibu Lilis, SP tersebut diketahui baru saja menjadi PPL pendamping Program PLDPM tersebut yaitu dalam waktu kurang lebih satu tahun yang di tempatkan wilayah kerja Kecamatan Senyerang sebagai PPL sekaligus pendamping program P-LDPM tersebut pada Gapoktan Sumber Rezeki di desa Teluk Ketapang. Sehingga banyak hal-hal yang tidak diketahui olehnya terkait seputar program terutama mengenai Juklak dan Juknis dari program. Sebelumnya, PPL yang mendampingi program ini terdiri dari dua orang yaitu Bapak Maman PPL Desa Senyerang dan Bapak Sahrum PPL Desa Bram Itam Kiri sesuai dengan Surat Keputusan Bupati Tanjung Jabung Barat Nomor 282 Tahun 2009 Tentang Tim Teknis Kegiatan Lembaga Distribusi Pangan Masyarakat (LDPM) Tahun 2009.

Adanya pergantian personal pendamping tidak diikuti dengan adanya transfer informasi yang lebih mendalam sehingga dapat menjadi hambatan tersendiri dalam mendampingi Gapoktan terutama dalam membantu baik masalah teknis maupun non teknis yang dibutuhkan oleh Gapoktan sesuai dengan tugas dan tanggung jawab Pendamping sesuai dengan Petunjuk Pelaksanaan (Juklak) Tahun 2014 tentang Kegiatan Penguatan Lembaga Distribusi Pangan Masyarakat (P-LDPM) yang ditetapkan oleh Badan Ketahanan Pangan Propinsi Jambi Tahun 2014.

\subsection{Kelompok Sasaran (Pengurus dan Anggota Gapoktan)}

Kelompok dapat memberi akses terhadap pelayanan ekonomi, namun pemanfaatannya belum optimal karena responden mayoritas hanya anggota pasif dan kapasitas kelompok bervariasi serta belum mampu mengembangkan jejaring kerjasama dengan pihak lain. 
Kebiasaan barter dan meminjam, baik yang berupa sembako dan uang sudah masih terus dilakukan. Hal ini dinyatakan oleh sebagian besar informan yang menyatakan tidak masih melakukan barter (tukar-menukar) barang bila tidak punya uang dan biasanya melakukan tukar menukar barang ini dengan tetangga, sementara yang melakukan dengan anggota keluarga inti (ayah, ibu, kakak, dan adik), kerabat dengan pedagang atau toko hanya sedikit sekali. Status sosial-ekonomi orang-orang yang melakukan barter sebagian besar melakukannya dengan orang-orang yang memiliki status sosial-ekonomi sama dan sedikit sekali dengan yang lebih kaya.Kondisi tersebut tidak berbeda jauh dengan kebiasaan meminjam sembako. Hal ini mengindikasikan keterbatasan jaringan/koneksi yang dimiliki responden, sehingga kemampuan untuk membantu responden dalam keadaan mendesak sangat terbatas.

Adanya komunikasi yang baik di antara implementor khususnya pihak pendamping dalam hal ini adalah PPL (Penyuluh Pertanian Lapangan) hal ini disebabkan adanya PPL yang kebetulan berasal dari masyarakat asli desa Teluk Ketapang itu sendiri. Oleh karenanya, komunikasi yang terbangun sangat baik antara pengurus dan anggota Gapoktan dengan PPL tersebut terutama dalam hal implementasi program P-LDPM tersebut.

Di samping itu, adanya jaringan komunikasi yang baik juga tercipta antara ketua Gapoktan Bapak Kasrun dengan pihak penanggungjawab program di tingkat Kabupaten yaitu pihak Kantor Badan Ketahanan Pangan sebagai tim pelaksana yang tunjuk melalui Surat Keputusan Bupati Tanjung Jabung Barat No. 131 Tahun 2011 Tanggal 28 Maret 2011 Tentang Pembentukan Tim Koordinasi Penanggulangan Kemiskinan Kabupaten Tanjung Jabung Barat, sudah terjalin komunikasi yang cukup baik dan sudah pernah menjalin hubungan kerjasama sebelumnya untuk berbagai kegiatan bantuan kepada Kelompok Tani, baik Bapak Kasrun selaku Ketua KUD maupun selaku Ketua BPD. Sehingga, antara Bapak Kasrun sudah saling mengenal dengan sebagian orang dari pihak Kantor tersebut.

Selain itu, di desa Teluk Ketapang ini terdapat satu orang anggota DPRD Kabupaten yang bernama Asek yang berasal dari Partai Gerindra yang sering memberikan berbagai informasi terkait yang berhubungan dengan pelaksanaan teknis maupun nonteknis diantaranya baik dalam usaha pembelian dan penjualan maupun dalam memberikan arahan dan bimbingan organisasi walaupun bapak Asek ini diketahui juga memiliki usaha penggilingan dan penyimpanan serta jual beli Padi dari warga.

Tetapi di sisi yang lain, karena di desa Teluk Ketapang terdapat beberapa pedagang pengumpul yang membeli dan menjual serta menggiling padi termasuk salah satunya Bapak Asek sebagai anggota DPRD Kabupaten Tanjung Jabung Barat ini menjadi kendala dan tantangan tersendiri bagi Gapoktan Sumber Rezeki di dalam menjalankan kegiatannya seperti dengan membeli gabah dengan harga mahal sesuai dengan HPP (Harga Pembelian Pemerintah) pada saat panen raya dan menjual murah pada saat kondisi usahatani petani lagi panceklik. Karena, hal ini akan sangat mengganggu bagi pedagang pengumpul lainnya dalam menjalankan bisnisnya sesuai dengan harga pasar.

Dengan demikian di dalam proses pelaksanaan program tesebut, pihak Gapoktan khususnya pengurusnya secara intens terlibat di dalamnya, baik secara formal maupun secara informal dengan memanfaatkan berbagai jaringan tersebut.

\subsection{Catatan Kritis Penelitian}

Dari penelitian yang dilakukan ditemukan di dalam masyarakat Desa Teluk Ketapang ini terdapat adanya kekuatan modal sosial lain yang dimanfaatkan oleh para petani selain kekuatan modal sosial di dalam Gapoktan tersebut. Modal sosial lain tersebut adalah adanya modal sosial yang dibangun oleh Bapak Asek yang juga memiliki usaha yang sama dengan usaha Gapoktan yaitu sebagai pengusaha yang juga melakukan pengumpulan dan pengolahan/penggilingan padi serta menjual beras yang ada di desa tersebut.

Keberadaan modal sosial yang dimiliki oleh Bapak Asek tersebut menjadi salah satu penghambat di dalam mengembangkan modal sosial di dalam Gapoktan Sumber Rezeki ini, karena terjadi adanya himpitan modal sosial di dalam masyarakat desa Teluk Ketapang, walaupun terdapat perbedaan bentuk modal sosial diantara keduanya, dimana modal sosial di dalam Gapoktan terdapat 
dalam struktur formal dengan misi sosial sedangkan modal sosial yang dimiliki Pak Asek berada di dalam struktur informal atau lebih pribadi dengan misi bisnis dan politik.

Modal sosial yang dimiliki struktur informal atau lebih pribadi yang cenderung memiliki misi lain berupa misi ekonomi dan politik merupakan modal sosial semu dengan mengeksploitasi sumbersumber modal sosial yang dimilikinya untuk kepentingan-kepentingan tertentu. Kondisi ini akan sangat mengancam nilai-nilai kejujuran di dalam kepercayaan yang terbangun.

Sejalan dengan pendapat Putnam, bahwa kepercayaan sosial pada dasarnya merupakan produk dari modal sosial yang baik. Adanya modal sosial yang baik ditandai oleh adanya lembaga-lembaga sosial yang kokoh; modal sosial yang melahirkan kehidupan sosial yang harmonis. Kerusakan modal sosial akan menimbulkan anomali dan prilaku antisosial. (Putnam, 2002)

\section{KESIMPULAN DAN SARAN}

\subsection{Kesimpulan}

sebagai berikut:

Berdasarkan uraian hasil penelitian dan pembahasan pada bab sebelumnya, dapat disimpulkan

Pemanfaatan modal sosial yang digunakan oleh implementor dalam implementasi program P-LDPM tersebut sangat membantu di dalam kelancaran pelaksanaan kegiatan di dalam program tersebut terutama di dalam memanfaatkan semangat kerjasama dan gotong royong serta solidaritas yang tinggi di dalam saling tolong menolong dan saling merasa senasib sepenanggungan di kalangan petani anggota Gapoktan Sumber Rezeki di desa Teluk Ketapang. Di samping itu, terdapat peran tokoh masyarakat yang dominan dan adanya peran Ketua Gapoktan yang sangat sentral di dalam menjalankan kegiatan di dalam implementasi program. Dengan kata lain, modal sosial trust lebih banyak digunakan dibandingkan modal sosial lain dan kapasitas modal sosial yang tersedia belum secara optimal dimanfaatkan untuk penanggulangan kemiskinan karena kelompok-kelompok yang tersedia memiliki keterbatasan akses untuk memberdayakan anggotanya.

\subsection{Saran-saran}

Berdasarkan hasil penelitian, sejumlah rekomendasi untuk mengoptimalkan modal sosial dalam penanggulangan kemiskinan adalah sebagai berikut:

1. Intervensi kebijakan untuk mengoptimalkan modal sosial dapat dilakukan pada modal sosial trust dan norma yang ada di dalam Gapoktan Sumber Rezeki terutama pada level mikro, melalui pemberdayaan keluarga, tetangga, kelompok pengajian, dan sebagainya.

2. Titik berat peningkatan kapasitas dapat difokuskan pada tokoh agama, tokoh pendidikan, dan tokoh kesehatan yang selama ini masih dipercaya oleh masyarakat. Keberadaan tokoh-tokoh ini dapat digunakan sebagai pendorong perubahan dalam modal sosial, dalam upaya mengubah relasi sosial yang kaku (transaksional) menjadi lebih luwes dan membangun jejaring kerja yang lebih luas serta kegiatan partisipasi yang lebih otonom. 


\section{DAFTAR PUSTAKA}

Badan Pusat Statistik, 2010. Survei Sosial Ekonomi Nasional (SUSENAS) 2005-2009. Propinsi Jambi. BPS.

, 2012. Survei Sosial Ekonomi Nasional (SUSENAS) 2010-2013. Propinsi Jambi. BPS. 2012. Survei Angkatan Kerja Nasional (SAKERNAS) 2011. Kabupaten Tanjung Jabung Barat. BPS. ,2011. Laporan Pelaksanaan Penanggulangan Kemiskinan Daerah (LP2KD) 2010. Kabupaten Tanjung Jabung Barat. TKPK.

Bappemdal, 2011. Laporan Akhir Penyusunan Strategi Penanggulangan Kemiskinan Daerah. Kabupaten Tanjung Jabung Barat.

Badan Ketahanan Pangan, 2014. Petunjuk Pelaksanaan Kegiatan Penguatan Lembaga Distribusi Pangan Masyarakat (P-LDPM). Propinsi Jambi

Badan Ketahanan Pangan, 2012. Pedoman Pelaksanaan Penguatan-Lembaga Distribusi Pangan Masyarakat (Penguatan-LDPM). Kementerian Pertanian

Badan Ketahanan Pangan, 2012. Pedoman Umum Penguatan-Lembaga Distribusi Pangan Masyarakat (Penguatan-LDPM). Pusat Distribusi dan Cadangan Pangan. Kementerian Pertanian

Coleman, S. J. (2011). Dasar-Dasar Teori Sosial (Foundations Of Social Theory). Nusa Media. Bandung.

Coleman, S. J. 1990. Foundation of Social Theory. Cambridge : Harvard University Press.

Denzin, K.N. dan Lincoln, S.Y. 2009. Handbook Of Qualitative Research. Pustaka Pelajar. Yogyakarta.

Field, J. (2010). Modal Sosial. Kreasi Wacana. Bantul.

Hasbullah, J. (2006). Social Capital (Menuju Keunggulan Budaya Manusia Indonesia). MR-United Press. Jakarta, Indonesia.

Ife, J. dan Tesoriero, F. 2008. Community Development. Pustaka Pelajar. Yogyakarta.

Kantor Ketahanan Pangan, 2012. Laporan Perkembangan Pelaksanaan Kegiatan P-LDPM Seluruh Gabungan Kelompok Tani (Gapoktan). Kabupaten Tanjung Jabung Barat.

Putnam, R. 1993. "Tuning In, Tuning Out : The Strange Disappearance of Social Capital in America". Political Studies Vol. 4 No. 28.

Silalahi, U. 2010. Metode Penelitian Sosial. Refika Aditama. Bandung.

Subarsono, A.G. 2013. Analisis Kebijakan Publik. Konsep, Teori dan Aplikasi.Pustaka Pelajar. Yogyakarta.

Spradley, J. (2006). Metode Etnografi (Kedua ed.). (M. Z. Elizabeth, Penerj.) Yogyakarta: Tiara Wacana.

Woolcock, M. 1998. Social capital and economic development : Toward a theoretical synthesis and policy framework. Theory and Society, 27 (2) : 151-208. 